\title{
Testy przesiewowe do badania umiejętności czytania i pisania
}

\section{Reading and writing abilities screening tests}

\author{
Aneta Domagała, Urszula Mirecka \\ Uniwersytet Marii Curie-Skłodowskiej, Zakład Logopedii i Językoznawstwa Stosowanego, Lublin
}

Adres autora: Aneta Domagała, Uniwersytet Marii Curie-Skłodowskiej, Zakład Logopedii i Językoznawstwa Stosowanego, ul. J. Sowińskiego 17, 20-040 Lublin, e-mail: aneta.domagala@onet.eu

\section{Streszczenie}

W artykule zaprezentowano testy przesiewowe wykorzystywane w Polsce do oceny umiejętności czytania i pisania osób objętych kształceniem obowiązkowym. Artykuł powstał na podstawie analizy narzędzi diagnostycznych oferowanych przez wiodące polskie pracownie testów psychologicznych, pedagogicznych i logopedycznych, analizy literatury przedmiotu poświęconej zagadnieniom diagnozy osób z trudnościami w czytaniu i pisaniu, a także na bazie doświadczeń własnych autorek, zebranych podczas wieloletniej pracy diagnostyczno-terapeutycznej, badawczej oraz dydaktycznej - opieki promotorskiej nad studentami kierunku logopedia z audiologią i słuchaczami Podyplomowych Studiów Logopedycznych prowadzącymi badania dotyczące problemów w komunikacji pisemnej.

Słowa kluczowe: testy przesiewowe $\bullet$ czytanie $\bullet$ pisanie

\begin{abstract}
The article presents the reading and writing abilities screening tests used in Poland to evaluate the skills of persons undergoing compulsory education. The study draws on three sources: diagnostic tools offered by leading Polish laboratories that produce psychological, pedagogical and logopedic tests, literature on diagnosing persons with writing and reading difficulties, and the personal experience of the authors, long involved in research of diagnostic, therapeutic, and pedagogical fields involving undergraduate and post-graduate students who have conducted research on problems in written communication.
\end{abstract}

Key words: screening tests $\bullet$ reading $\bullet$ writing

\section{Wprowadzenie}

Testy przesiewowe do badania umiejętności czytania i pisania należą do technik diagnostycznych stosowanych w badaniach przesiewowych w celu wyłonienia osób wymagających pomocy ze względu na już występujące lub mogące się pojawić problemy w opanowaniu komunikacji pisemnej, postrzegane przez nas jako zaburzenia komunikacji językowej [1]. Jak podają Krasowicz-Kupis, Wiejak i Gruszczyńska [2, s. 34], „termin badanie przesiewowe oznacza ocenę członków pewnej populacji, na przykład grupy dzieci, w celu określenia prawdopodobieństwa wystąpienia u nich jakiegoś zjawiska - pewnych cech, zachowań, problemów, zaburzeń czy predyspozycji - np. specyficznych zaburzeń uczenia się czy predyspozycji matematycznych lub muzycznych". Z uwagi na cele, charakter i formę badań, badania przesiewowe dotyczące umiejętności czytania i pisania prowadzone są zwykle na terenie placówek edukacyjnych, do których uczęszczają dzieci. Wpisują się one w działania o charakterze profilaktycznym - odpowiednio wczesne zidentyfikowanie osób, w stosunku do których należy podjąć interwencję (pedagogiczną, logopedyczną czy psychologiczną), stanowi ważny etap w zapobieganiu zaburzeniom, a w przypadku wystąpienia trudności przyczynia się do ich minimalizowania. Badania przesiewowe bywają prowadzone nie tylko w formie badań indywidualnych, lecz także grupowych, z reguły są krótsze i mniej wnikliwe niż pełne badania diagnostyczne - stwierdzenie obniżonego poziomu ocenianych umiejętności daje podstawę jedynie do wskazania prawdopodobieństwa występowania określonego zaburzenia; jego zdiagnozowanie jest możliwe $\mathrm{w}$ pełnym, często wielospecjalistycznym badaniu diagnostycznym, w którym oprócz symptomów analizowane są także przyczyny zaburzeń. Niskie wyniki w testach przesiewowych powinny stanowić podstawę skierowania dziecka na badania specjalistyczne (np. do poradni psychologiczno-pedagogicznej) oraz decyzji o objęciu ucznia dodatkowymi formami zajęć mających na celu stymulację słabiej rozwijających się funkcji zaangażowanych w czynności czytania i pisania (językowych, słuchowych, wzrokowych, kinestetyczno-ruchowych, integracji percepcyjno-motorycznej) oraz kształtowanie umiejętności czytania i pisania. 
Celem niniejszego artykułu jest prezentacja testów przesiewowych wykorzystywanych w Polsce do oceny umiejętności czytania i pisania osób objętych kształceniem obowiązkowym. Artykuł powstał na podstawie analizy testów oferowanych przez wiodące polskie firmy wydające testy psychologiczne, pedagogiczne i logopedyczne, analizy literatury przedmiotu poświęconej zagadnieniom diagnozy osób $\mathrm{z}$ trudnościami w czytaniu i pisaniu, a także na bazie doświadczeń własnych autorek, zebranych podczas wieloletniej pracy diagnostyczno-terapeutycznej oraz dydaktycznej - opieki promotorskiej nad studentami kierunku logopedia z audiologią i słuchaczami Podyplomowych Studiów Logopedycznych prowadzącymi badania dotyczące problemów w komunikacji pisemnej.

Prezentacja testów podzielona została w artykule na części odpowiadające aktualnie obowiązującym w Polsce, według danych Polskiego Biura Eurydice (Sieć Informacji o Edukacji w Europie) [3], etapom kształcenia obowiązkowego, które dotyczy osób w wieku od 5 do 16 roku życia i obejmuje rok obowiązkowej edukacji przedszkolnej (wiek 5 lat), sześć lat szkoły podstawowej (podzielonej na dwa etapy: I etap - wiek 6/7-10 lat, II etap - wiek 10-13 lat) oraz trzy lata gimnazjum (wiek 13-16 lat).

\section{Testy przesiewowe stosowane na etapie edukacji przedszkolnej}

Od 1 września 2011 r., w związku z wprowadzonym od 2014 r. obniżeniem wieku szkolnego, obowiązkowe roczne przygotowanie przedszkolne, realizowane w przedszkolach i innych formach wychowania przedszkolnego, obejmuje dzieci 5-letnie, a także 6-latki, których rodzice nie zgodzili się na wysłanie ich do szkoły (taka możliwość istniała do 2015 roku) [3]. Do celów edukacji w wieku przedszkolnym zaliczane jest m.in. „kształtowanie umiejętności porozumiewania się z otoczeniem (mowa ustna i pisana)" [4, s. 11], a dziecko 6-letnie kończące ten etap edukacji określone zostało, w kontekście interesujących nas tutaj kompetencji, jako "gotowe do opanowania umiejętności czytania i pisania” [4, s. 65]. Zatem testy przesiewowe przeznaczone do badania tej grupy dzieci obejmuja ocenę nie czynności czytania i pisania, lecz funkcji psychomotorycznych, które są angażowane w ich przebiegu.

Do testów przesiewowych stosowanych na etapie edukacji przedszkolnej należą:

1. Bateria metod diagnozy rozwoju psychomotorycznego dzieci pięcio- $i$ sześcioletnich - wersja skrócona (autorzy: Marta Bogdanowicz, Dorota Kalka, Urszula Sajewicz-Radtke, Bartosz M. Radtke) [5].

Narzędzie diagnostyczne przeznaczone jest do badań przesiewowych dzieci w wieku 5;00-6;11, a jego użytkownikami mogą być psycholodzy, pedagodzy, logopedzi, nauczyciele, terapeuci zatrudnieni w szkołach i przedszkolach. Za pomocą tego narzędzia możliwa jest wstępna diagnoza rozwoju psychomotorycznego, składa się ono bowiem $\mathrm{z}$ testów diagnozujących funkcje wzrokowo-przestrzenne (m.in. koordynację wzrokowo-ruchową, percepcję wzrokowo-przestrzenną), funkcje słuchowo-językowe (m.in. analizę i syntezę głoskową), rozwój poznawczy (m.in. kategoryzowanie, porównywanie zbiorów), sprawność motoryki małej (m.in. sprawność grafomotoryczną na materiale nieliterowym), sprawność motoryki dużej (m.in. zdolność utrzymania równowagi), orientację $\mathrm{w}$ schemacie ciała i przestrzeni, zdolność do kontroli emocji oraz rozwój społeczny. Normalizacja narzędzia została przeprowadzona w roku 2010.

2. Skala Gotowości Edukacyjnej Pięciolatków (SGE-5). Obserwacyjna metoda dla nauczycieli (autorzy: Elżbieta Koźniewska, Andrzej Matuszewski, Elżbieta Zwierzyńska) [6].

Narzędzie diagnostyczne do badań przesiewowych jest znormalizowaną skalą obserwacyjną do stosowania przez nauczycieli przedszkola w badaniach 5-letnich dzieci w oddziałach rocznego przygotowania przedszkolnego. Ocenie podlega m.in. przygotowanie dzieci do nauki czytania i pisania, a wyniki odnoszą się do 4 podskal obejmujących kompetencje poznawcze, aktywność w sferze poznawczo-emocjonalnej, sprawność psychomotoryczną i odporność emocjonalną. Obserwowane są zachowania dziecka wskazujące na rozwój jego uwagi, pamięci, myślenia (czynności umysłowych typu: klasyfikowanie, szeregowanie, rozumienie sensu umownych znaczeń, myślenie przyczynowo-skutkowe), języka (zdolności narracyjnych, sprawności fonologicznych), komunikowania się, zdolności arytmetycznych, wiedzy o świecie, koordynacji zmysłowo-ruchowej i sprawności ruchowej (szczególnie: manualnej). Normalizacja skali została przeprowadzona w roku 2009.

3. Test do badania zagrożenia dysleksja SWM (autorzy: Marta Korendo, Jagoda Cieszyńska) [7].

Przesiewowy test SWM (Słuch-Wzrok-Mowa) umożliwia logopedom, psychologom, pedagogom, nauczycielom przedszkola i terapeutom wczesnej interwencji badanie zagrożenia dysleksją dzieci od 3. do 7. roku życia (zawiera normy dla 3-, 4-, 5- i 6-latków). Zadania testowe, odrębne dla poszczególnych poziomów wieku, służą do oceny dominacji stronnej (określenie dominacji oka, ucha, ręki i nogi), funkcji słuchowych (ocena poziomu rozwoju sekwencyjnej pamięci słuchowej w próbach powtarzania samogłosek, sylab i wyrazów), funkcji wzrokowych (ocena poziomu rozwoju analizy i syntezy wzrokowej w próbach układania wzoru z klocków i układanki tematycznej), użycia języka (w zakresie artykulacji i komunikacji), pamięci sekwencyjnej (ocena sekwencyjnej pamięci wzrokowej w próbach zapamiętywania sekwencji obrazków) i grafopercepcji (ocena sprawności manualnej, koordynacji wzrokowo-ruchowej oraz umiejętności ujmowania relacji).

Zaprezentowane testy przesiewowe przeznaczone do badania dzieci na etapie edukacji przedszkolnej wykazują szereg podobieństw, ale też różnią się pod pewnymi względami; za najistotniejsze uznać można kwestie dotyczące zakresu oraz sposobu badania:

- Test do badania zagrożenia dysleksja SWM ukierunkowany jest na problem dysleksji, toteż zawarte w nim zadania obejmują ocenę funkcji psychomotorycznych, których zaburzenia powodować mogą wystąpienie specyficznych trudności w czytaniu i pisaniu, natomiast $\mathrm{Ba}$ teria metod diagnozy rozwoju psychomotorycznego dzieci pięcio- i sześcioletnich oraz Skala Gotowości Edukacyjnej Pięciolatków (SGE-5) mają bardziej ogólny charakter ocenie podlega więcej funkcji poznawczych (m.in. myślenie, uwaga), a także sfera emocjonalna i społeczna; 
- Bateria metod diagnozy rozwoju psychomotorycznego dzieci pięcio- i sześcioletnich oraz Test do badania zagrożenia dysleksją SWM składają się z prób, które dziecko ma wykonywać w trakcie indywidualnego badania diagnostycznego, natomiast Skala Gotowości Edukacyjnej Pięciolatków (SGE-5) jest metodą, którą można stosować, przeprowadzając jednorazowo obserwację 10 dzieci, zaznaczając w arkuszu obserwacyjnym, czy i jak często określone zachowania pojawiają się u poszczególnych osób.

\section{Testy przesiewowe stosowane na I etapie nauki w szkole podstawowej}

$\mathrm{Na}$ I etapie nauki w szkole podstawowej, nazywanym edukacją wczesnoszkolną, badaniami przesiewowymi obejmowane są zasadniczo dzieci w wieku 6/7-10 lat. Badania prowadzone są na początku nauki szkolnej bądź w trakcie jej trwania - oceniane jest więc przygotowanie do nauki czytania i pisania lub poziom opanowania tych umiejętności w toku ich nauki.

Do testów przesiewowych stosowanych na etapie edukacji wczesnoszkolnej należą:

1. Skala Funkcjonowania Pierwszoklasisty (SFP) (autorzy: Elżbieta Koźniewska, Elżbieta Zwierzyńska, Andrzej Matuszewski) [8].

Narzędzie diagnostyczne jest znormalizowaną skalą obserwacyjną do stosowania przez nauczycieli edukacji wczesnoszkolnej w badaniach przesiewowych w pierwszym semestrze I klasy (badanie dzieci w wieku 5;10-6;10). Ocenie podlega m.in. przygotowanie dzieci do nauki czytania i pisania; wyniki odnoszą się do 5 podskal obejmujących umiejętności szkolne, kompetencje poznawcze, sprawność motoryczną, samodzielność dziecka, umiejętności społeczne (niekonfliktowość) i poziom aktywności społecznej. Obserwowane są zachowania dziecka wskazujące m.in. na rozwój jego procesów poznawczych (uwagi, myślenia operacyjnego i przyczynowo-skutkowego, zdolności kategoryzowania, reprezentacji pojęciowej), języka (zdolności narracyjnych, umiejętności fonologicznych), komunikowania się, zdolności arytmetycznych, sprawności grafomotorycznej, sprawności ruchowej. Normalizacja skali została przeprowadzona w latach 2011/2012.

2. Skala Ryzyka Dysleksji dla dzieci wstępujących do szkoły (autor: Marta Bogdanowicz; współautor podręcznika: Dorota Kalka) [9].

Narzędzie diagnostyczne ma charakter obserwacyjny, ujęte jest w postać kwestionariuszową, umożliwia pedagogom, logopedom i psychologom dokonywanie wstępnej oceny zagrożenia wystąpieniem specyficznych trudności w czytaniu i pisaniu u dzieci rozpoczynających naukę szkolną (w wieku 6;00-6;11). Opracowanie wyników, wraz z odniesieniem ich do norm, obejmuje ogólną i szczegółową (w 4 podskalach) ocenę rozwoju funkcji uczestniczących w czynnościach czytania i pisania, w tym: motorykę (małą i dużą), funkcje wzrokowe, funkcje językowe (percepcję i ekspresję) oraz uwagę. Badania przesiewowe przeprowadzone za pomocą tego narzędzia pozwalają wyłonić nie tylko dzieci z ryzykiem dysleksji, lecz także z innymi zaburzeniami uczenia się. Dostępne są także wersje komputerowe tego narzędzia $[10,11]$, pozwalające na uproszczenie procedury opracowywania wyników, ich analizowania i gromadzenia, ułatwiające proces ich interpretacji. Normalizacja skali została przeprowadzona w roku 2010.

3. Skala Ryzyka Dysleksji wraz z normami dla klas I i II (autor: Marta Bogdanowicz) [12].

Narzędzie diagnostyczne ma charakter obserwacyjny, ujęte jest w postać kwestionariuszową, umożliwia pedagogom, logopedom i psychologom dokonywanie wstępnej oceny zagrożenia wystąpieniem specyficznych trudności w czytaniu i pisaniu u dzieci kończących klasy I i II (7- i 8-letnich). Opracowanie wyników, wraz z odniesieniem ich do norm, obejmuje ogólną i szczegółową (w 4 podskalach) ocenę rozwoju funkcji uczestniczących w czynnościach czytania i pisania, w tym: motorykę (małą i dużą), funkcje wzrokowe, funkcje językowe (percepcję i ekspresję) oraz uwagę. Badania przesiewowe przeprowadzone za pomocą tego narzędzia pozwalają wyłonić nie tylko dzieci z ryzykiem dysleksji, lecz także z innymi zaburzeniami uczenia się. Normalizacja skali została przeprowadzona w latach 1999/2000.

\section{Test czytania głośnego - Dom Marka (autor: Marta Bog-} danowicz) [13].

Test jest przeznaczony dla psychologów, pedagogów i logopedów do diagnozy umiejętności czytania głośnego uczniów kończących pierwszy rok nauki czytania (w wieku 6;11-7;11). Umożliwia ocenę znajomości liter i cyfr, tempa, techniki i poprawności czytania, a także poziomu rozumienia samodzielnie czytanego tekstu. Test, wraz ze Skala Ryzyka Dysleksji M. Bogdanowicz, jest zalecany w przypadku przesiewowych badań pod kątem diagnozy specyficznych trudności w czytaniu, zarówno w warunkach szkolnych, jak i w poradniach psychologiczno-pedagogicznych [2]. Normalizacja testu została przeprowadzona w roku 2009.

5. Test Dekodowania (autorzy: Marcin Szczerbiński, Olga Pelc-Pękala) [14].

Narzędzie diagnostyczne przeznaczone jest dla psychologów i pedagogów badających uczniów klas pierwszych szkoły podstawowej, niezależnie od wieku rozpoczęcia nauki (6- i 7-latków). Test składa się z dwóch zasadniczych części: I - testów osiągnięć odnoszących się do czytania i II - testów świadomości fonologicznej oraz testów tempa nazywania. Do badań przesiewowych stosowane są jedynie testy osiągnięć, obejmujące znajomość liter, znajomość cyfr, czytanie słów prawdziwych i czytanie słów sztucznych. Normalizacja testu została przeprowadzona w roku 2012.

6. Bateria metod diagnozy przyczyn niepowodzeń szkolnych u dzieci ośmioletnich - wersja skrócona (autorzy: Marta Bogdanowicz, Dorota Kalka, Urszula Sajewicz-Radtke, Bartosz M. Radtke) [15].

Narzędzie przeznaczone jest dla psychologów i pedagogów szkolnych dokonujących diagnozy przesiewowej specyficznych trudności w czytaniu i pisaniu u osób w wieku 8;00-8;11. Składa się z testów diagnozujących: funkcje 
wzrokowo-przestrzenne, funkcje słuchowo-językowe oraz czytanie i pisanie. Badanie funkcji wzrokowych obejmuje ocenę percepcji wzrokowo-przestrzennej i szybkości spostrzegania wzrokowego (w zadaniach $\mathrm{z}$ wykorzystaniem materiału wizualnego). Funkcje słuchowo-językowe diagnozowane są na podstawie prób dotyczących słuchu fonemowego, pamięci fonologicznej, analizy i syntezy głoskowo-fonemowej oraz prób uwagi i pamięci fonologicznej. Próby czytania głośnego obejmują ocenę dekodowania (z użyciem wyrazów bezsensownych), w czytaniu tekstu ocenę tempa, techniki i poprawności czytania oraz rozumienia czytanego tekstu, a próby pisania obejmują ocenę ortografii, interpunkcji oraz aspektów graficznych (m.in. błędy konstrukcyjne, nieprawidłowe proporcje liter, błędy w łączeniu liter w wyrazach, nieprawidłowa wielkość i pochylenie liter). Normalizacja narzędzia została przeprowadzona w latach 2008/2009.

Zaprezentowane narzędzia przesiewowe przeznaczone do badania dzieci na etapie edukacji wczesnoszkolnej różnią się przede wszystkim zakresem oraz sposobem badania:

- Ze względu na zakres badania omawiane testy można uszeregować - według zmniejszającej się liczby ocenianych funkcji/umiejętności - następująco: Skala Funkcjonowania Pierwszoklasisty (SFP), Bateria metod diagnozy przyczyn niepowodzeń szkolnych u dzieci ośmioletnich, Skala Ryzyka Dysleksji (obie wersje), Test Dekodowania, Test czytania głośnego - Dom Marka;

- Ze względu na sposób badania omawiane narzędzia można podzielić na dwa typy: skale obserwacyjne (Skala Funkcjonowania Pierwszoklasisty oraz obie wersje Skali Ryzyka Dysleksji) i testy składające się z prób, które dziecko ma wykonywać w trakcie indywidualnego badania diagnostycznego (Bateria metod diagnozy przyczyn niepowodzeń szkolnych u dzieci ośmioletnich, Test Dekodowania, Test czytania głośnego - Dom Marka).

\section{Testy przesiewowe stosowane na II etapie nauki w szkole podstawowej}

$\mathrm{Na}$ II etapie nauki w szkole podstawowej, obejmującym klasy IV-VI (uczniowie w wieku 10-13 lat), liczba przesiewowych technik diagnostycznych drastycznie maleje znajduje się tutaj tylko jeden test: Bateria metod diagnozy przyczyn niepowodzeń szkolnych u uczniów w wieku 10-12 lat - wersja skrócona (autorzy: Marta Bogdanowicz, Dorota Kalka, Elżbieta Karpińska, Urszula Sajewicz-Radtke, Bartosz M. Radtke) [16].

Narzędzie przeznaczone jest dla psychologów i pedagogów szkolnych dokonujących diagnozy przesiewowej specyficznych trudności w czytaniu i pisaniu u osób w wieku 10;00-12;11. Składa się z testów diagnozujących: funkcje wzrokowo-przestrzenne, funkcje słuchowo-językowe oraz czytanie. W ramach oceny funkcji wzrokowych badana jest percepcja wzrokowo-przestrzenna i szybkość spostrzegania wzrokowego. Funkcje słuchowo-językowe diagnozowane są na podstawie prób słuchu fonemowego, pamięci fonologicznej, analizy i syntezy głoskowo-fonemowej oraz uwagi i pamięci fonologicznej. Próby czytania dotyczą czytania głośnego (z użyciem wyrazów bezsensownych), oceniane jest dekodowanie. Normalizacja narzędzia została przeprowadzona w roku 2012.

\section{Testy przesiewowe stosowane na etapie nauki} w gimnazjum

Jedyną techniką diagnostyczną przeznaczoną do badań przesiewowych w grupie gimnazjalistów jest: Bateria metod diagnozy przyczyn niepowodzeń szkolnych u uczniów gimnazjów - wersja skrócona (autorzy: Marta Bogdanowicz, Dorota Kalka, Elżbieta Karpińska, Urszula Sajewicz-Radtke, Bartosz M. Radtke) [17].

Narzędzie przeznaczone jest do stosowania przez psychologów oraz pedagogów szkolnych w diagnozie przesiewowej specyficznych trudności w czytaniu i pisaniu u osób w wieku 13;00-16;00, pozwalając na wstępną ocenę rozwoju funkcji percepcyjno-motorycznych i językowych, które leżą u podstaw umiejętności czytania i pisania. Bateria składa się z testów diagnozujących m.in. percepcję wzrokowo-przestrzenną, sprawność ruchową, dominację stronną, integrację wzrokowo-słuchową, słuch fonemowy, uwagę i pamięć fonologiczną, umiejętność dokonywania analizy i syntezy głoskowo-fonemowej, pamięć werbalną. Normalizacja narzędzia została przeprowadzona w roku 2011.

\section{Zastosowanie metod eksperymentalnych w badaniach przesiewowych}

$\mathrm{W}$ badaniach przesiewowych bywają stosowane, obok testów stricte przesiewowych, także narzędzia o charakterze eksperymentalnym, wykorzystywane zwykle w badaniach porównawczych, w procedurach badań eksperymentalnych. Przykładem jest test Prolexia, zaproponowany przez Obera, Jaśkowską, Jaśkowskiego i Ober jako nowa metoda oceny rozwoju funkcji czytania [18]. To eksperymentalne narzędzie do badania umiejętności czytania w zakresie dekodowania i rozumienia czytanego tekstu (składające się z testu słów oraz zdań łańcuchowych) stosowane w badaniach naukowych [np. 19,20], wykorzystywane jest również w badaniach przesiewowych, prowadzonych na poziomie edukacji wczesnoszkolnej oraz w klasach IV-VI szkoły podstawowej [np. 21]. Atuty testu Prolexia to: 1) krótki czas badania (3 minuty na każdy z testów), 2) możliwość prowadzenia zarówno badań indywidualnych, jak i grupowych, 3) w związku z oceną dwu wymiarów czynności czytania sprawności dekodowania fonologicznego i rozumienia czytanego tekstu - możliwość wskazania trudności w czytaniu o charakterze dysleksji bądź hiperleksji. Problemem jest brak normalizacji testu Prolexia, co nie pozwala na ocenę jego diagnostyczności i trafności klinicznej [20].

\section{Testy przesiewowe stosowane w Wielkiej Brytanii}

Stosowane w Wielkiej Brytanii testy przesiewowe dotyczące umiejętności czytania i pisania ukierunkowane są na problemy osób z dysleksją oraz ze specjalnymi potrzebami edukacyjnymi. Angela Fawcett, prezentując na konferencji Nowe trendy $w$ diagnozie specyficznych zaburzeń uczenia się (zorganizowanej przez Instytut Badań Edukacyjnych w Warszawie w dniach 25-26 listopada 2014 r.) zagadnienia skuteczności wczesnych badań przesiewowych oraz interwencji wśród dzieci z ryzykiem dysleksji, wskazała na potrzebę prowadzenia wieloaspektowej diagnostyki w szerokim przedziale wiekowym. Na baterię 
angielskich testów przesiewowych, których współautorką jest A. Fawcett, składają się:

1. Pre-School Screening Test (PREST) [22] - przeznaczony do badania dzieci ze specjalnymi potrzebami edukacyjnymi w wieku 3;6-4;5.

2. Dyslexia Early Screening Test - Second Edition (DEST-2) [23] - przesiewowy test dysleksji przeznaczony do badania dzieci w wieku 4;6-6;5.

3. Dyslexia Screening Test - Junior (DST-J) [24] - przesiewowy test dysleksji przeznaczony do badania dzieci w wieku 6;6-11;5.

4. Dyslexia Screening Test - Secondary (DST-S) [25] - przesiewowy test dysleksji przeznaczony do badania dzieci w wieku 11;6-16;5.

5. Dyslexia Adult Screening Test (DAST) [26] - przeznaczony do badania osób w wieku powyżej 16;5, w przypadkach podejrzenia dysleksji i innych trudności w uczeniu się.

Testy obejmują rozmaite próby służące do oceny funkcji i umiejętności niezbędne do opanowania czytania i pisania - polegają np. na szybkim nazywaniu, rozróżnianiu fonemów, wykrywaniu rymów, powtarzaniu cyfr, kopiowaniu kształtów, pisaniu pod dyktando, czytaniu nonsensownego tekstu; oceniana jest także płynność werbalna i semantyczna, stabilność pionowej postawy ciała, sprawność manualna, tempo pisania.

\section{Wnioski}

1. Jak wynika z zaprezentowanego materiału, dostępne w Polsce testy przesiewowe do badania umiejętności czytania i pisania sprofilowane są przede wszystkim pod kątem wykrywania dysleksji i ryzyka dysleksji. W projektowanych narzędziach należałoby poszerzyć zakres ocenianych zjawisk, zarówno w aspekcie objawowym, jak i przyczynowym.
2. Więcej testów poświęconych jest ocenie umiejętności czytania niż ocenie umiejętności pisania. W projektowanych narzędziach należałoby zatem w większym stopniu uwzględnić problematykę pisania.

3. W ocenie czytania pomijany jest aspekt prozodii czytanego tekstu. W projektowanych narzędziach należałoby włączyć ocenę płaszczyzny suprasegmentalnej w próbach głośnego czytania tekstów.

4. W badaniu umiejętności pisania ocena dotyczy głównie poprawności pisowni. W projektowanych narzędziach należałoby uwzględnić tworzenie wypowiedzi pisemnej oraz ocenę grafomotoryki (ocenę wytworu czynności grafomotorycznych i obserwację przebiegu czynności pisania).

5. Zbyt mało testów przesiewowych przeznaczonych jest do badania uczniów klas IV-VI szkoły podstawowej i gimnazjum, brakuje również testów przesiewowych do badania osób powyżej 16 roku życia. Warto byłoby zatem opracować narzędzia do badań przesiewowych w tych przedziałach wiekowych.

6. $Z$ uwagi na to, że autorzy zaprezentowanych narzędzi nie podają informacji dotyczących możliwości i/lub ograniczeń ich stosowania wobec dzieci i młodzieży z uszkodzonym słuchem, wykorzystanie ich w badaniach przesiewowych tej grupy osób wydaje się możliwe jedynie przy współudziale specjalistów zajmujących się rehabilitacją i edukacją dzieci z uszkodzonym słuchem - zarówno na etapie badania (wymagającego w wielu przypadkach dostosowania instrukcji i poleceń do możliwości odbiorczych uczniów), jak i na etapie analizy oraz interpretacji wyników badań ( $\mathrm{z}$ uwzględnieniem wpływu uszkodzenia słuchu na wyniki uzyskane w testach).

Artykuł powstał $w$ zwiąku z realizacja projektu „Zintegrowany system narzędzi do diagnostyki i telerehabilitacji schorzeń narzadów zmysłów (stuchu, wzroku, mowy, równowagi, smaku, powonienia)" wspótfinansowanego przez Narodowe Centrum Badań i Rozwoju w ramach Programu STRATEGMED.

\section{Piśmiennictwo:}

1. Domagała A, Mirecka U. Standard postępowania logopedycznego w przypadku dysleksji rozwojowej. Logopedia, 2008; 37: $116-25$.

2. Krasowicz-Kupis G, Wiejak K, Gruszczyńska K. Katalog metod diagnozy rozwoju poznawczego dziecka na etapie edukacji przedszkolnej i wczesnoszkolnej (tom I - narzędzia dostępne w poradniach psychologiczno-pedagogicznych i szkołach). Warszawa: Instytut Badań Edukacyjnych; 2015.

3. Krótki opis polskiego systemu edukacji. www.eurydice.org.pl/ wp-content/uploads/2014/10/NSO_PL_2014_0.pdf.

4. Molińska M, Ratajczak A. Edukacja przedszkolna. Warszawa: Instytut Badań Edukacyjnych; 2014.

5. Bogdanowicz M, Kalka D, Sajewicz-Radtke U, Radtke BM. Bateria metod diagnozy rozwoju psychomotorycznego dzieci pięcio- i sześcioletnich - wersja skrócona. BATERIA-5/6S [B-5/6 „S”]. Gdańsk: Pracownia Testów Psychologicznych i Pedagogicznych; 2011.

6. Koźniewska E, Matuszewski A, Zwierzyńska E. Skala Gotowości Edukacyjnej Pięciolatków (SGE-5). Obserwacyjna metoda dla nauczycieli. http://www.bc.ore.edu.pl Warszawa: Ośrodek Rozwoju Edukacji; 2010.
7. Korendo M, Cieszyńska J. Test do badania zagrożenia dysleksją SWM. Kraków: Wydawnictwo Metody Krakowskiej; 2012.

8. Koźniewska E, Zwierzyńska E, Matuszewski A. Skala Funkcjonowania Pierwszoklasisty (SFP). Adaptacja SGS dla nauczycieli I klasy SP. http://www.bc.ore.edu.pl Warszawa: Ośrodek Rozwoju Edukacji; 2013.

9. Bogdanowicz M, Kalka D. Skala Ryzyka Dysleksji dla dzieci wstępujących do szkoły. SRD-6. Gdańsk: Pracownia Testów Psychologicznych i Pedagogicznych; 2011.

10. Bogdanowicz M, program: Radtke BM, Fomiczow A. Skala Ryzyka Dysleksji dla dzieci wstępujących do szkoły (SRD-6) wersja komputerowa - licencja jednostanowiskowa [eSRD-1]. Gdańsk: Pracownia Testów Psychologicznych i Pedagogicznych; 2011.

11. Bogdanowicz M, program: Radtke BM, Fomiczow A. Skala Ryzyka Dysleksji dla dzieci wstępujących do szkoły (SRD-6) wersja komputerowa - licencja dziesięciostanowiskowa [eSRD10]. Gdańsk: Pracownia Testów Psychologicznych i Pedagogicznych; 2011.

12. Bogdanowicz M. Ryzyko dysleksji, dysortografii i dysgrafii Skala Ryzyka Dysleksji wraz z normami dla klas I i II. Gdańsk: Wydawnictwo Harmonia; 2011. 
13. Bogdanowicz M. Test czytania głośnego - Dom Marka. [DM]. Gdańsk: Pracownia Testów Psychologicznych i Pedagogicznych; 2012.

14. Szczerbiński M, Pelc-Pękala O. Zestaw metod diagnozy trudności w czytaniu. Test Dekodowania. Gdańsk: Pracownia Testów Psychologicznych i Pedagogicznych; 2013.

15. Bogdanowicz M, Kalka D, Sajewicz-Radtke U, Radtke BM. Bateria metod diagnozy przyczyn niepowodzeń szkolnych u dzieci ośmioletnich - wersja skrócona. BATERIA-8S [B-8 „S”]. Gdańsk: Pracownia Testów Psychologicznych i Pedagogicznych; 2010.

16. Bogdanowicz M, Kalka D, Karpińska E, Sajewicz-Radtke U, Radtke BM. Bateria metod diagnozy przyczyn niepowodzeń szkolnych u uczniów w wieku 10-12 lat - wersja skrócona. BATERIA-10/12S [B-10/12 „S”]. Gdańsk: Pracownia Testów Psychologicznych i Pedagogicznych; 2013.

17. Bogdanowicz M, Kalka D, Karpińska E, Sajewicz-Radtke U, Radtke BM. Bateria metod diagnozy przyczyn niepowodzeń szkolnych u uczniów gimnazjów - wersja skrócona. BATERIA-GIMS [B-GIM „S”]. Gdańsk: Pracownia Testów Psychologicznych i Pedagogicznych; 2012.
18. Ober J, Jaśkowska E, Jaśkowski P, Ober JJ. Propozycja nowej metody oceny rozwoju funkcji czytania - test słów i zdań lańcuchowych. Logopedia, 1998; 25: 81-96.

19. Brzezińska A. Poziom umiejętności czytania uczniów szkół podstawowych. Forum Oświatowe, 2004; 2(31): 11-30.

20. Nowotnik A. Funkcjonowanie uwagi a poziom umiejętności czytania u dzieci w wieku wczesnoszkolnym. Edukacja, 2013; 1(121): 71-86.

21. Biekisz J, Sztandera A. Badania przesiewowe skuteczną profilaktyką niepowodzeń szkolnych uczniów na poziomie edukacji wczesnoszkolnej. www.ore.edu.pl [dostęp 26.06.2015 r.]

22. Fawcett A, Nicolson R, Lee R. Pre-School Screening Test (PREST). Pearson Education; 2001.

23. Nicolson R, Fawcett A. Dyslexia Early Screening Test - Second Edition (DEST-2). Pearson Education; 2004.

24. Fawcett A, Nicolson R. Dyslexia Screening Test - Junior (DST-J). Pearson Education; 2004.

25. Fawcett A, Nicolson R. Dyslexia Screening Test - Secondary (DST-S). Pearson Education; 2004.

26. Fawcett A, Nicolson R. Dyslexia Adult Screening Test (DAST). Pearson Education; 1998. 